\title{
ACHENE MORPHOLOGY AND ITS TAXONOMIC SIGNIFICANCE IN THE GENUS PYCREUS (CYPERACEAE) OF GOA, INDIA
}

\author{
*Ramchandra T. Patili1 and V.P. Prasad ${ }^{2}$ \\ ${ }^{1}$ Department of Botany, Gopal Krishna Gokhale College, Kolhapur, Maharashtra - 416012 \\ ${ }^{2}$ Central National Herbarium, Botanical Survey of India, Howrah, West Bengal - 711103 \\ *Author for Correspondence: E-mail: patilrtvengurla@rediffmail.com
}

Communicated : 14.04.19
Revision : 10.05 .19

Accepted : 26.05 .19
Published: 30.05.19

\begin{abstract}
:
Taxonomic relationship among the species of Pycreus in Goa is elucidated by examining the scanning electron microscope (SEM) images of their achenes. Morphology of the achenes and their epidermal cells has been studied for this purpose with a taxonomic viewpoint. Achene shape and epidermal patterns were found distinctive and consistent within the species or infraspecific taxon. Variation in the epidermal cells is most evident with respect to size of the cell, nature of periclinal wall, the number, thickness and sinuosity of anticlinal walls and presence or absence of silica bodies. In the present study characteristics of epidermal cells are correlated with other morphological characters as well. The micromorphological characters of achene surface were found to be different in dissimilar taxa. However, there is close similarity of these characters in closely related taxa. Interpretation of the SEM images was found to be useful in determining the taxonomic relationship, identification and delimitation of different taxa of Pycreus at species level and infraspecific level.
\end{abstract}

Key words: - SEM images, Achene morphology, Pycreus, Silica bodies, Anticlinal wall.

\section{INTRODUCTION: \\ INTRODUCTION}

The family Cyperaceae is one of the ten largest families of flowering plants and is the third largest of monocotyledons after Orchidaceae and Poaceae. Bruhl (1995) estimated approximately 5,000 species in about 80 genera and Goetghebeur (1998) included same number of species under 104 genera. But according to Mabberley (2009) there are 92 genera and 4450 species, and Govaerts et al. (2015) reported 97 accepted genera and 5486 species of Cyperaceae. Singh and Prasad (2001) estimated about 570 species of 39 genera in India and the present number is estimated to be about 580 species belonging to 32 genera (Patil and Prasad, (2016). In Goa it is represented by 94 species, 2 subspecies and 9 varieties belonging to16 genera.

The genus Pycreus P. Beauv. of this family is very similar to Cyperus L. and hence, often treated together under the later sensu lato. However, Pycreus can be easily separated from Cyperus by an unique and constant character, i.e. its laterally compressed achenes, with one of the two edges towards the rachilla. But in Cyperus one face of the trigonous or laterally compressed achenes is towards the rachilla. At global level the genus has about 100 species (Mabberley, 2009) and is confined to tropical countries. A total number of 38 species of Pycreus are reported from India of which 7 have been reduced to synonyms by Prasad (2009, 2015). A total number of 8 species and one variety have been reported from Goa (Patil, 2013) and all were studied for their achene morphology. All the species have a wide range of distribution except $P$. malabaricus C.B. Clarke which is endemic to western and southern India, in the states of Maharashtra, Goa, Karnataka, Kerala and Tamilnadu.

The first basic study on epidermal silica bodies of the achenes was accomplished by Schuyler (1971) on two species of Scirpus L. and Eriophorum L. that lead to the development of a new set of characters that could re-evaluate the systematics of Cyperaceae. Varma et al. (1989) studied the epidermal surface patterns of the achenes in Eleocharis, Govindrajalu (1990) studied SEM images of Pycreus sect. Muricati. and Wujek et al. (1992) did the achene micromorphology of some Indian species of Cyperus, Fimbristylis, Pycreus, 
Scirpus and Scleria. Also Menapace et al. (2003) did the achene micromorphology of some Indian species as a possible systematic aid to the taxonomic recognition of different sections in Fimbristylis. Recently Patil and Prasad (2016, 2016a) revealed the micromorphology of the achenes of the genera Fimbristylis and Eleocharis found in Goa.

In the present study achenes of 9 taxa belonging to genus Pycreus in Goa have been studied and interpreted for their similarities and dissimilarities. The study includes gross morphology such as achene size, shape etc. using conventional methodology and the micro-epidermal cell structures like nature of periclinal wall and anticlinal wall, presence or absence of silica bodies, if present the shape and number of silica bodies per cell, etc. using SEM images.

\section{MATERIAL AND METHODS :-}

Achene samples were collected from the plant specimens collected from different localities in Goa. The specimens collected were identified utilising available facilities in Botanical Survey of India, Pune and the herbarium in Goa University. The herbarium specimens from which achene samples were taken are deposited in BSI. For better result, mature specimens were selected to study the morphology of achenes by conventional method using stereo microscope and by the advanced method of interpreting the Scanning Electron Microscope (SEM) images. The shape and size of the achenes of each species were recorded and the micro structure of the achene surface was studied using SEM images. For this, achenes were extracted from the spikelets and mounted on glass slides with sticky tape, mounted on SEM stubs and then sputter coated with platinum and examined under JOEL JSM6360 Scanning Electron Microscope. The images were then photographed at different magnifications. The SEM images of the achenes of different species thus obtained were then interpreted with the help of relevant literature. Achene shape, size, its ornamentations and microepidermal structures such as nature of periclinal walls, anticlinal walls and silica bodies were studied to find out the similarities or dissimilarities.

\section{RESULT \& DISCUSSION}

The genus Pycreus is characterized by bilaterally flattened achenes with one angle facing the rachilla of the spikelet. In all the 8 species, achene is biconvex and the shape in general is obovate or oblong with variations like obovate to obovateelliptic in $P$. diaphanus, obovate to oblong-elliptic in $P$. flavidus, globose-obovate in $P$. malabaricus, broadly obovate to orbicular in $P$. sanguinolentus, broadly elliptic to obovate-orbicular in $P$. stramineus, oblong in $P$. polystachyos, oblong to obovate in $P$. macrostachyos and oblong-obovate in $P$. pumilus. The largest achene is found $P$. macrostachyos (1.5-2 x 0.6-1.37 $\mathrm{mm}$ ) while the smallest in $P$. pumilus $(0.5-0.8 \times 0.3-0.5 \mathrm{~mm})$. Achene in the variety gracilescens of $P$. diaphanus is smaller than the typical variety. Important findings are provided in table 1 and the SEM images of the achenes are shown in plate $1 \& 2$.

All the eight species were studied for their achene morphology. Besides the shape, size and colour of the achene, its surface is very important in the classification of the species of Pycreus. Achene surface is transversely wrinkled with longitudinally oblong epidermal cells in $P$. diaphanus, $P$. malabaricus and $P$. stramineus. But in all other species in Goa achene surface is smooth to finely reticulate with isodiametric epidermal cells. Both Pycreus diaphanus and $P$. flavidus possess inconspicuous, smaller silica bodies without elevation at the centre of each epidermal cell. But these two can be differentiated by the presence of prominent nodular projections at the junction of anticlinal walls of nearby cells in $P$. diaphanus and by the inconspicuous projections in $P$. flavidus. Achenes of $P$. macrostachyos and $P$. polystachyos are with very similar microstructure on achene surface, but both have mesa-shaped silica bodies at the centre of epidermal cells. These two can be separated based on achene size. P. macrostacyos have larger achene $(1.5-2 \times 0.6-1.37 \mathrm{~mm})$ than $P$. polystachyos (1-1.5 x 0.4-0.5 $\mathrm{mm})$. The two varieties of $P$. pumilus i.e. $P$. pumilus var. membranaceus and P. pumilus var. pumilus are very similar in their achene microstructure and both have silica bodies in the epidermal cells. So, these varieties cannot be separated using micromorphological characters of the achenes, but mainly by the arrangement of the glumes on the rachilla. Another very closely related species of Pycreus are $P$. malabaricus and $P$. stramineus which are separated mainly by colour of the spikelets, but shows similarity in achene size, shape and epidermal microstructure. In both the species silica bodies are absent and have distinct epidermal pattern than other species of Pycreus. Both possess linear or longitudinally oblong epidermal cells with transversally ridged, sinnulate and longitudinally 
straight, sritullate anticlinal walls in the epidermal cells.

In $P$. sanguinolentus silica bodies are absent on achene surface. Achene in this species is distinct from other taxa, being obovate-orbicular and by the presence of a notch at posterior region of the achene. Thus in Pycreus both macromorphology and micromorphlogy of the achene is very useful for identifying, and delimiting different taxa.

\section{ACKNOWLEDGEMENTS}

The authors thank the Director, Botanical Survey of India, Kolkata and the Head of Office, BSI, Pune, for the facilities. Prof. M.K. Janarthanam, Department of Botany, Goa University kindly extended all the facilities in his department and permitted to work in the University Herbarium. Thanks are due to Head of the Physics Department, Shivaji University, Kolhapur, for the SEM images of achenes. The help from the Forest Department officials of Goa during the field work is thankfully acknowledged. The first author is indebted to the Principal, Gopal Krishna Gokhale College, Kolhapur, for the encouragement.

\section{REFERENCES:-}

Bruhl JJ (1995). Sedge genera of the world: relationships and a new classification of the

Cyperaceae. Austral. Syst. Bot. 8 125-305.

Goetghebeur P (1998). Cyperaceae. In: Kubitzki, K., Huber, H. Rudall, P. J., Stevens, P. S. and T. Stützel (eds.) The families and genera of vascular plants Vol. 4. Springer-Verlag, Berlin. pp. 141190.

Govaerts R, Koopman J, Simpson DA, Goetghebeur P, Wilson K, Egorova $\mathrm{T}$ and J Bruhl (2015). World Checklist of Selected Plant Families. Facilitated by the Royal Botanic Gardens, Kew. Published on the Internet; http://apps.kew.org/wcsp/ Retrieved 2015-0107.

Govindarajalu E (1990). Cyperaceae Indiae Australis Precursores: New species and scanning electron microscopic observations in Pycreus sect. muricati. Proc. Indian Acad. Sci.100 415-422.
Mabberley DJ (2009). Mabberley's Plant-Book (3rd edition reprinted with corrections). Cambridge University Press, Cambridge. p. 247.

Menapace FJ, Wujek DE and BHM Nijalingappa (2003). Achene micromorphology of some Indian Cyperaceae. V. Achene micromorphology as a possible systematic aid to the taxonomic recognition of Fimbristylis sections. Bull. Bot. Surv. India 4 521-28.

Patil RT (2013). Taxonomic studies on family Cyperaceae in Goa with added emphasis on nut morphology. Unpublished Ph.D. thesis, University of Pune.

Patil RT and VP Prasad (2016). Achene morphology and its taxonomic significance in Cyperaceae of Goa, India: 1. Genus Eleocharis. Indian J. Pl. Sci. 5(1): 9-14.

Patil RT and VP Prasad (2016a). Achene morphology and its taxonomic significance in Cyperaceae of Goa, India: 1. Genus Fimbristylis. Indian J. Pl. Sci. 5(1): 87-96.

Prasad VP (2009). Five new synonyms of Pycreus malabaricus (Cyperaceae). Rheedea19 19-24.

Prasad VP (2015). Pycreus bolei and P. lancelotii two new synonyms of $P$. pumilus (Cyperaceae). Nelumbo 57: 37-39.

Schuyler AE (1971). Scanning electron microscopy of achene epidermis in species of Scirpus (Cyperaceae) and related genera. Proc. Acad. Nat. Sci. Philadelphia 123 29-52.

Singh NP and VP Prasad (2001). CYPERACEAE In: Singh, N.P. and D.K. Singh eds. Floristic Diversity and Conservation Strategies in India. Vol. IV. B.S.I, Kolkata.pp. 1983-2026.

Varma SK, Pandey AK and AK Sinha (1989). Epidermal surface patterns of achene in Eleocharis R. Br. (Cyperaceae). Curr. Sci. 58 1374-1377.

Wujek DE, Verma SK and RA Ruhlman (1992). Achene micromorphology of some Indian Cyperaceae (Cyperus, Fimbristylis, Pycreus, Scirpus, and Scleria). Asian J. Pl. Sci. 4 1-19. 
Table 1. Macro- and micro-morphology of achenes in the genus Pycreus

\begin{tabular}{|c|c|c|c|}
\hline $\begin{array}{l}\text { Sr. } \\
\text { No. }\end{array}$ & $\begin{array}{l}\text { Plant name and } \\
\text { voucher specimen }\end{array}$ & Macromorphology & $\begin{array}{c}\text { Micromorphology } \\
\text { (interpretation of SEM images) }\end{array}$ \\
\hline 1. & $\begin{array}{l}\text { Pycreus diaphanus } \\
\text { (Schrad. ex Roem. \& } \\
\text { Schult.) S. Hooper \& T. } \\
\text { Koyama } \\
\text { Bastora, Ucassaim, near } \\
\text { St. Elizabeth's church, } \\
\text { Bardez Taluk, North } \\
\text { Goa, 20.9.2007, R.T. } \\
\text { Patil } 192641 \text { (BSI) } \\
\text { PLATE } 1\end{array}$ & $\begin{array}{l}\text { Biconvex, laterally sub- } \\
\text { compressed, obovate to } \\
\text { obovate-elliptic, shortly } \\
\text { apiculate at apex, } \\
\text { narrowed at base, } 0.94 \mathrm{x} \\
0.85 \mathrm{~mm} \text {. }\end{array}$ & $\begin{array}{l}\text { Epidermal cells transversely } \\
\text { oblong, irregularly hexagonal; } \\
\text { anticlinal wall thick, straight, } \\
\text { raised; periclinal wall smooth, } \\
\text { flat, with inconspicuous smaller } \\
\text { silica bodies, without elevation at } \\
\text { the centre of each cell. Prominent } \\
\text { nodular projections were found } \\
\text { at the junction of antclinal walls } \\
\text { of nearby cells. }\end{array}$ \\
\hline 2. & $\begin{array}{l}\text { Pycreus flavidus (Retz.) } \\
\text { T. Koyama } \\
\text { Parra, Bardez Taluk, } \\
\text { North Goa, } 17.10 .2006 \text {, } \\
\text { R.T. Patil } 192510 \text { (BSI). } \\
\text { PLATE } 1\end{array}$ & $\begin{array}{l}\text { Biconvex, laterally } \\
\text { compressed, obovate to } \\
\text { oblong-elliptic, shortly } \\
\text { apiculate at apex, } \\
\text { narrowed at base, } 1.06 \mathrm{x} \\
0.87 \mathrm{~mm} \text {. }\end{array}$ & $\begin{array}{l}\text { Epidermal cells isodiametric, } \\
\text { hexagonal; anticlinal wall thick, } \\
\text { straight, raised; periclinal wall } \\
\text { smooth, flat, with minute silica } \\
\text { bodies without much elevation at } \\
\text { the centre of each cell. } \\
\text { Inconspicuous nodular } \\
\text { projections were found at the } \\
\text { junction of } 4 \text { anticlinal walls of } \\
\text { nearby cells. }\end{array}$ \\
\hline 3. & $\begin{array}{l}\text { Pycreus macrostachyos } \\
\text { (Lam.) J. Raynal } \\
\text { Dona Paula-Miramar } \\
\text { road, Tiswadi Taluk, } \\
\text { North Goa, } 24.11 .2006, \\
\text { R.T. Patil } 192518 \text { (BSI). } \\
\text { PLATE } 1\end{array}$ & $\begin{array}{l}\text { Biconvex, laterally } \\
\text { compressed, oblong- } \\
\text { obovate, concave on one } \\
\text { surface, apiculate at the } \\
\text { obtuse apex, slightly } \\
\text { stipitate, } 1.84 \times 1.37 \mathrm{~mm} .\end{array}$ & $\begin{array}{l}\text { Epidermal cells sub-isodiametric, } \\
\text { hexagonal; anticlinal wall } \\
\text { straight but indistinct; periclinal } \\
\text { wall convex with mesa-shaped } \\
\text { silica bodies at the centre of each } \\
\text { cell. Buttresses not prominent. }\end{array}$ \\
\hline 4. & $\begin{array}{l}\text { Pycreus malabaricus } \\
\text { C.B. Clarke } \\
\text { Tivim,Bardez Taluk, } \\
\text { North Goa, 9.9.2007, } \\
\text { R.T. Patil } 192608 \text { (BSI). } \\
\text { PLATE } 1\end{array}$ & $\begin{array}{l}\text { Biconvex, slightly laterally } \\
\text { compressed, ovate to } \\
\text { obovate-elliptic, } \\
\text { asymmetric, minutely } \\
\text { apiculate at the obtuse } \\
\text { apex, } 0.91 \times 0.65 \mathrm{~mm} .\end{array}$ & $\begin{array}{l}\text { Epidermal cells linear or } \\
\text { longitudinally oblong; anticlinal } \\
\text { wall transversally ridged and } \\
\text { sinnulate while longitudinally } \\
\text { straight stritullate; periclinal wall } \\
\text { smooth, flat, without silica } \\
\text { bodies. }\end{array}$ \\
\hline 5. & $\begin{array}{l}\text { Pycreus polystachyos } \\
\text { (Rottb.) P. Beauv. } \\
\text { Quepem, near court, } \\
\text { Quepem Taluk, South } \\
\text { Goa, 22.4.2007, R.T. } \\
\text { Patil 192564 (BSI). } \\
\text { PLATE } 2\end{array}$ & $\begin{array}{l}\text { Biconvex, laterally } \\
\text { compressed, narrowly } \\
\text { oblong or oblong-obovate, } \\
\text { sub-truncate and minutely } \\
\text { apiculate at apex, stipitate. } \\
1.12 \times 0.5 \mathrm{~mm} .\end{array}$ & $\begin{array}{l}\text { Epidermal cells sub-isodiametric, } \\
\text { hexagonal; anticlinal wall } \\
\text { straight but inconspicuous; } \\
\text { periclinal wall convex with mesa- } \\
\text { shaped single silica body in each } \\
\text { cell; buttresses not prominent. }\end{array}$ \\
\hline
\end{tabular}




\begin{tabular}{|c|c|c|c|}
\hline 6. & $\begin{array}{l}\text { Pycreus pumilus } \\
\text { (L.) Nees var. pumilus } \\
\text { Valpoi, Sattari Taluk, } \\
\text { North Goa, 22.9.2007, } \\
\text { R.T. Patil 192673(BSI). } \\
\text { PLATE } 2\end{array}$ & $\begin{array}{l}\text { Biconvex, laterally } \\
\text { compressed, oblong- } \\
\text { obovoid, minutely } \\
\text { apiculate at the obtuse } \\
\text { apex, minutely stipitate, } \\
0.65 \times 0.37 \mathrm{~mm} \text {. }\end{array}$ & $\begin{array}{l}\text { Epidermal cells isodiametric, } \\
\text { hexagonal; anticlinal wall } \\
\text { straight, weakly depressed; } \\
\text { periclinal wall smooth, convex, } \\
\text { with mesa-shaped silica bodies } \\
\text { arranged in longitudinal rows; } \\
\text { buttresses not prominent. }\end{array}$ \\
\hline 7. & $\begin{array}{l}\text { Pycreus pumilus } \\
\text { var. membranaceus } \\
\text { (Vahl) Karthik. } \\
\text { Mulgaon, Shirodwadi, } \\
\text { Bicholim Taluk, North } \\
\text { Goa, 9.9.2007, R.T. Patil } \\
\text { 192614 (BSI). } \\
\text { PLATE } 2\end{array}$ & $\begin{array}{l}\text { Biconvex, laterally } \\
\text { compressed, obovoid- } \\
\text { oblong, minutely apiculate } \\
\text { at the obtuse apex, } \\
\text { minutely stipitate, } 0.55 \mathrm{x} \\
0.41 \mathrm{~mm} \text {. }\end{array}$ & $\begin{array}{l}\text { Epidermal cells isodiametric, } \\
\text { hexagonal; anticlinal wall } \\
\text { straight, weakly depressed; } \\
\text { periclinal wall smooth, convex, } \\
\text { with mesa-shaped silica bodies } \\
\text { arranged in longitudinal rows; } \\
\text { buttresses not prominent. }\end{array}$ \\
\hline 8. & $\begin{array}{l}\text { Pycreus sanguinolentus } \\
\text { (Vahl) Nees) } \\
\text { Valpoi, Koparde Fata, } \\
\text { Sattari Taluk, North } \\
\text { Goa, 22.9.2007, R.T. } \\
\text { Patil 192670 (BSI). } \\
\text { PLATE } 2 \\
\end{array}$ & $\begin{array}{l}\text { Biconvex, laterally } \\
\text { compressed, obovate- } \\
\text { orbicular, minutely } \\
\text { apiculate at the obtuse } \\
\text { apex, notched at the } \\
\text { posterior region, } 1.18 \mathrm{x} \\
1.21 \mathrm{~mm} \text {. }\end{array}$ & $\begin{array}{l}\text { Epidermal cells irregular } \\
\text { hexagonal-polygonal; anticlinal } \\
\text { wall thick, straight, raised; } \\
\text { periclinal wall smooth, flattened; } \\
\text { silica bodies absent. Achene } \\
\text { surface wavy at low resolution, } \\
\text { wrinkled. }\end{array}$ \\
\hline 9 & $\begin{array}{l}\text { Pycreus stramineus C.B. } \\
\text { Clarke } \\
\text { Mulgaon, Shirodwadi, } \\
\text { Bicholim Taluk, North } \\
\text { Goa, 9.9.2007, R.T. Patil } \\
\text { 192612 (BSI). } \\
\text { PLATE } 2\end{array}$ & $\begin{array}{l}\text { Biconvex, laterally } \\
\text { compressed, ovate to } \\
\text { obovate-elliptic, } \\
\text { asymmetric, minutely } \\
\text { apiculate at the obtuse } \\
\text { apex, } 0.92 \times 0.75 \mathrm{~mm} .\end{array}$ & $\begin{array}{l}\text { Epidermal cells linear or } \\
\text { longitudinally oblong; anticlinal } \\
\text { wall transversally ridged and } \\
\text { sinnulate while longitudinally } \\
\text { straight stritullate; periclinal wall } \\
\text { smooth, flat, without silica } \\
\text { bodies. }\end{array}$ \\
\hline
\end{tabular}




\section{SEM MICROGRAPHS OF PYCREUS P. BeaUv. ACHENES PLATE 1}
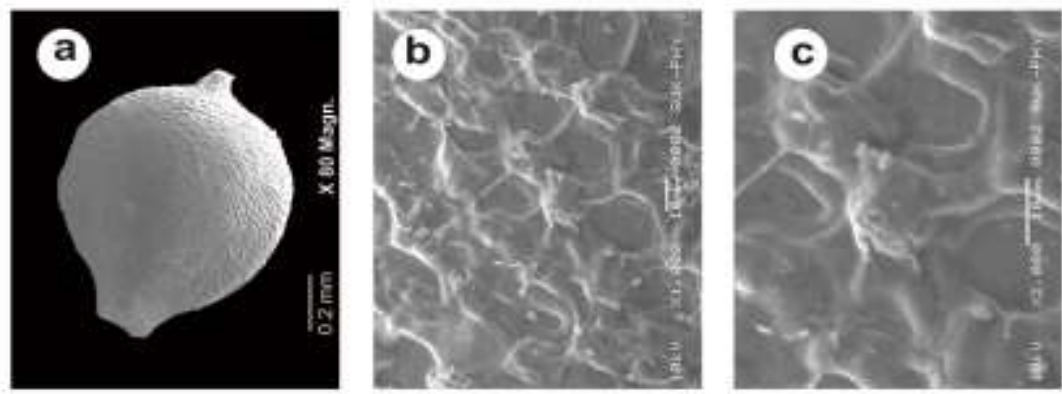

Pycreus diaphamus (Schrad. ex Roem. \& Schult.) S.S. Hooper \& T. Koyami - a. Achene, b. \& c. Epidermal cells
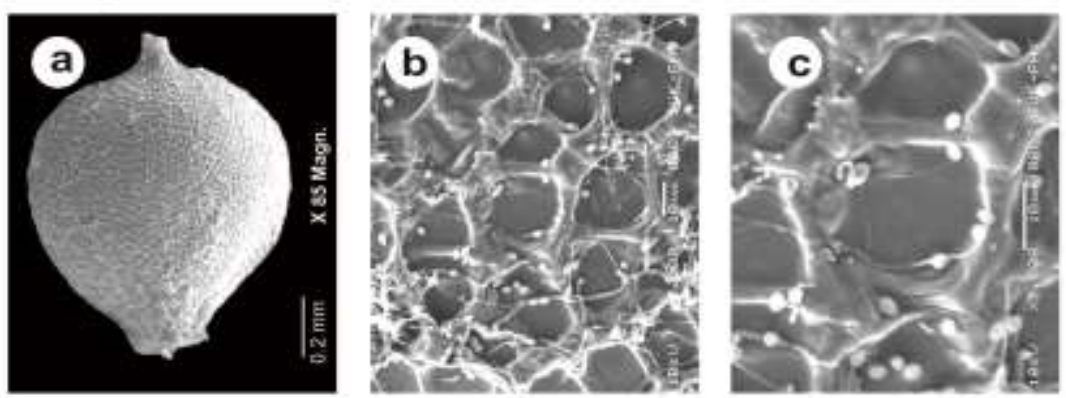

Pycreus flavidus (Retz.) T. Koyama - a. Achene, b \& c. Epidermal cells
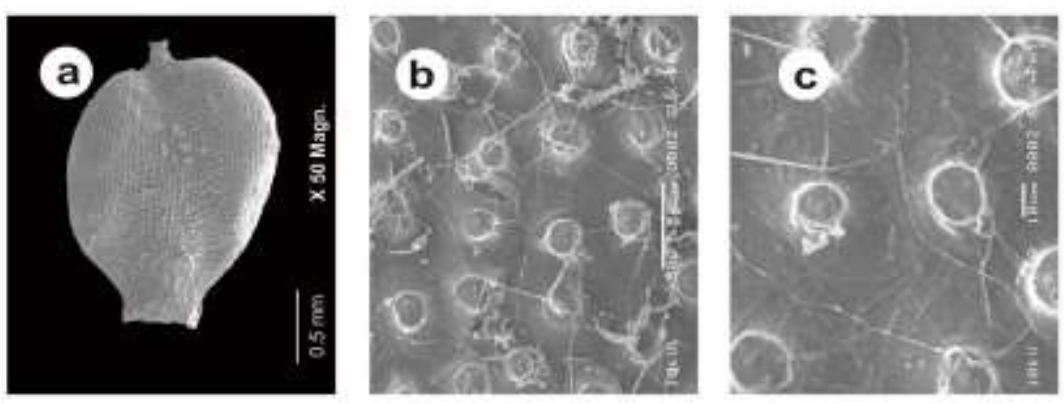

Pycreus macrostachyos (Lam.) J. Raynal - a. Achene, b \& c, Epidermal cells
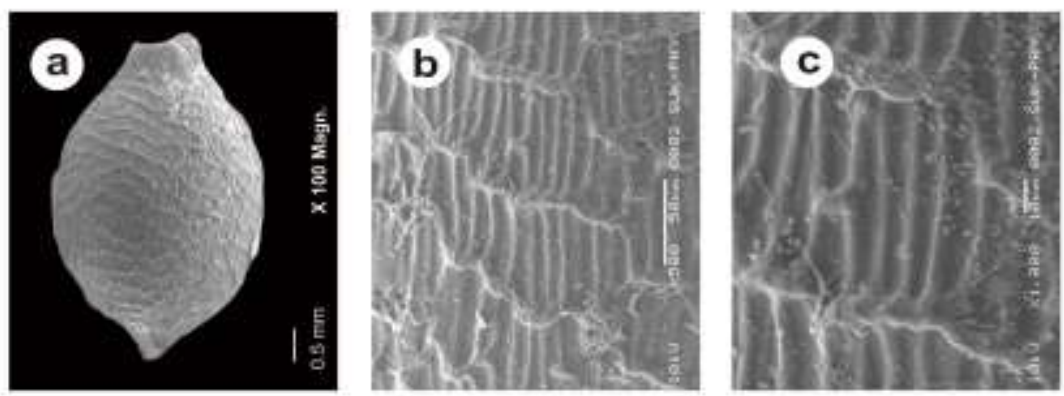

Pycreus malabaricus C.B. Clarke - a. Achene, b \& c. Epidermal cells 
I J R B A T, Issue (VII), Vol. II, May 2019: 15-21

A Double Blind Peer Reviewed Journal

OPEN $\rightarrow$ ACCESS

e-ISSN 2347 - 517X

Original Article

\section{PLATE 2}
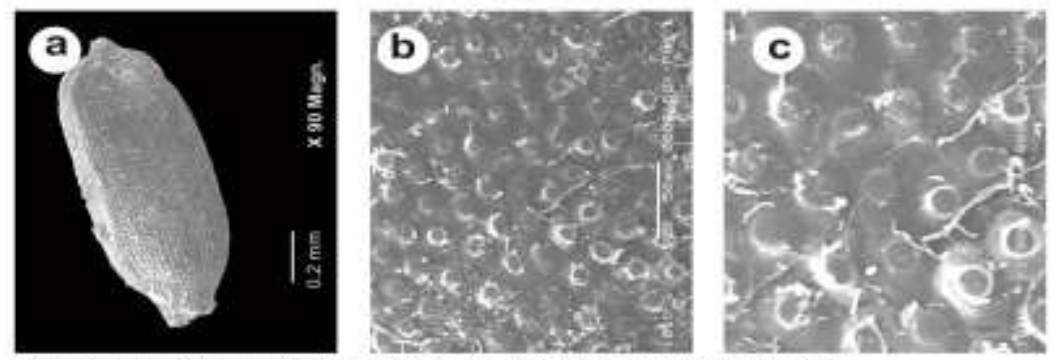

Pycreus polystachyos (Roub.) P. Besuv. - a. Achenc, b \& c, Epidermal cells
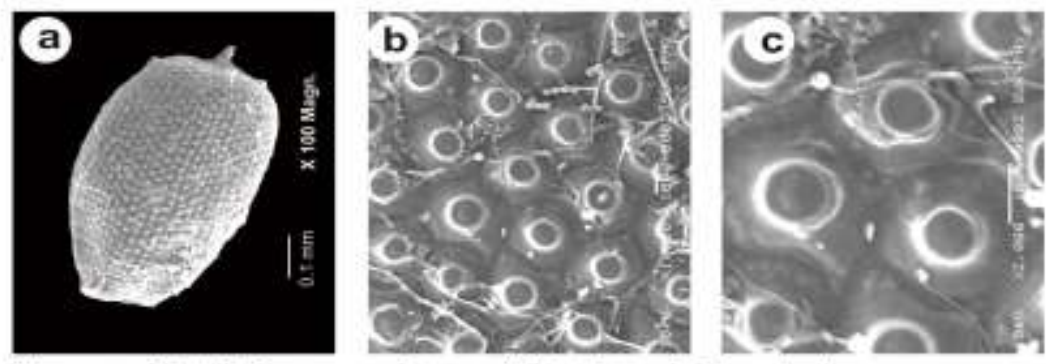

Pyereus pumilus (L.) Nees var, pumilus - a. Achene, b \& c. Epidermal cells
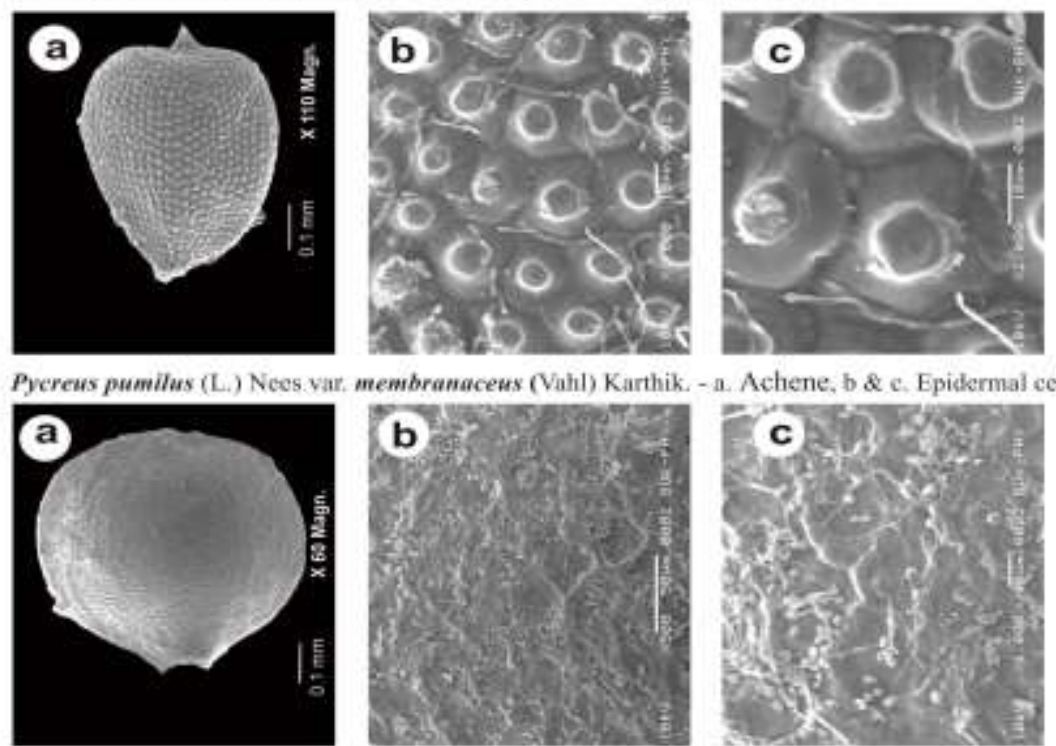

- a. Achene, b \& c. Epidermal cell

Pycreus sanguimolentus (Vahl) Nees - a. Achene, b \& c. Epidermal cells
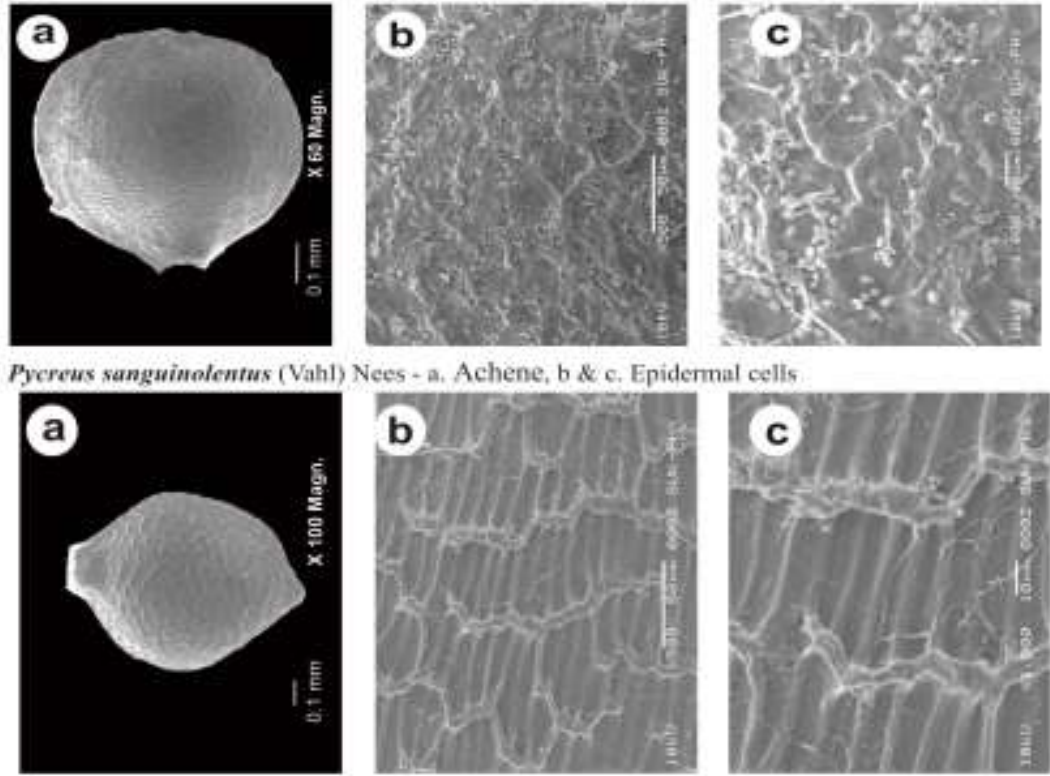

Pycreus stramineus C. B. Clarke - a. Achene, b \& c. Epidermal cells 